\title{
Using Ideas from Connectivism for Designing New Learning Models in Vietnam
}

\author{
Nguyen Manh Hung
}

\begin{abstract}
Connectivism is new learning theory that is expanding traditional learning theories (behaviorism, cognitivism and constructivism) in the world that deeply impacted by internet and technology. This paper is intended to highlight some ideas extracted from connectivism and using them for suggesting the models of Learning Ecosystem and Connective Open Online Course (COOC) with the intention on practical using for education reformation process in Vietnam.
\end{abstract}

Index Terms - Connectivism, connective open online course (COOC), learning ecosystem, MOOC.

\section{Connectivism AND Highlighted IDEAS}

We are exposing the total engagement of internet in our life, in our work, everywhere. We can use Google for searching, Wikipedia for finding necessary knowledge, Facebook or Twitter for social connection, Flickr for sharing photos and YouTube for sharing videos. These are only very few among numerous applications of technology that we are using every day. Technology is transforming totally almost all social and economic fields, especially finance and banking, engineering and manufacturing, medicine and science applying. The most out-of-date, in term of using technology, maybe is education, that still has been being in framed model of teacher-learner and classroom model of teaching and learning.

The main limitations of this education are noted by connectivists [1], [2]: 1) content-based and expert-based content: the current education is mainly focused on transferring knowledge to learners based on fixed content and programs prepared by only experts such as teachers, professors, educators; 2) lack of non-human learning: learning process does not allow non-human actor like technology, and this is limiting the ability of using technology in the depth of learning process; 3) enclosed structures and spaces of learning process: almost all learning activities happen within such boudaries like classroom or homework; 4) content-based learning rather than contextual.

In order to have alternative and supplementary learning theory to three (03) traditional ones - Behaviorism, Cognitivism, Constructivism - Siemens G. has proposed new learning theory based on chaos, self-organization and network theories [2].

The main principles of the connectivism are noted by Siemens G. [2]:

- Learning and knowledge rests in diversity of opinions.

- Learning is a process of connecting specialized nodes or information sources.

Manuscript received June 17, 2013; revised September 11, 2013.

Nguyen Manh Hung is with Hanoi National University of Education, Ha Noi, Vietnam (e-mail: hungnm@hnue.edu.vn).
- Learning may reside in non-human appliances.

- Capacity to know more is more critical than what is currently known

- Nurturing and maintaining connections is needed to facilitate continual learning.

- Ability to see connections between fields, ideas, and concepts is a core skill.

- Currency (accurate, up-to-date knowledge) is the intent of all connectivist learning activities.

- Decision-making is itself a learning process. Choosing what to learn and the meaning of incoming information is seen through the lens of a shifting reality.

This paper does not attempt to have explanatory comments on connectivism, indeed it will focus on some exciting ideas for application in learning practice, especially in Vietnam.

Education reformation in Vietnam is defined as crucial strategy for national development, that why a "new, fundamental and comprehensive" education reform has been proposed by government. The reform is addressing to total and fundamental change of existing education system, that still is highly affected by legacy and academic educational approach. This reform has to face on biggest barries from culture and mechanism wall. There are content-based education curricula and programs, which are focusing on remembering concrete facts and figures only; there are expert-based teaching approaches that relied on educators only; there are social behaviours that mobilize all learning efforts for highest score in national examination in order to ensure one "seat" for learning in higher education. In order to contribute to this reform, some ideas from connectivism could be fine for a design of new learning models that uplift these mentioned barriers [3], [4].

\section{A. Movement of Knowledge and Connective Knowledge}

The fundamental point from connectivism as noted by Siemens, G. is that thesis of learning as a process of forming connections:

"Learning is a process of connecting specialized nodes or information sources" [2] and "I perceive learning as a network formation process" [5].

On the same way, Downes S. has been noted the concept of connective knowledge. Beside of two main types of knowledge from ancient era so far - qualitative and quantitative - Downes S. has been described the third type of knowledge as connective:

Distributed knowledge adds a third major category to this domain, knowledge that could be described as connective. A property of one entity must lead to or become a property of another entity in order for them to be considered connected; the knowledge that results from such connections is connective knowledge." [1].

From this concept, Downes describes "connectivism is the thesis that knowledge is distributed across a network of 
connections, and therefore that learning consists of the ability to construct and traverse those networks" [1].

Thus, we can imagine that knowledge has been created in a network and has been traversing the network to create other ones. This is movement of knowledge and the fastest rate of this movement at this digital era is a cause of booming knowledge of human nowadays.

\section{B. An Impact of Technology Is Leading to Expansion of Learning Spaces and Structures of Existing Education System}

As we have been seeing, from long time ago up to now, traditional education is defined by two elements of organization: bounded classrooms and hierarchical structure of learning content based on an hierarchical mindset. Thus, huge forces so far for reforming education system have not been touched to this classroom structure. As an implication of connectivism, Siemens has suggested new structures and spaces of learning based on impact of networked learning, connectivism and connective knowledge. He has proposed a concept of 1) learning ecology of limitless dimensions of learning, and 2) new structure and spaces of learning, based on moving away from hierarchy and classrooms, and a pedagogy of participation to change play roles between teachers and learners in term of more connectivity between them [6].

Highly inspired from this idea of learning ecology and new learning structures, this paper is trying to suggest a holistic concept of learning ecosystem, which involves technology and other elements in full ecosystem for nurturing and developing learning process. The theoretical model and practical design of this learning ecosystem will be explained with more details in next part of this paper.

\section{Using Open Technology Base to Connect People for Learning through Massive Open Online Courses (MOOC)}

The connectivist learning style has been designed when pioneers of connectivism began conducting first massive open online course (CCK08) [7]. As noted by Downes, this learning style is associated with openness, diversity, autonomy, network and connectivity principles [8].

The connectivist style of MOOC (cMOOC) is being an origin for a vast development of MOOC, and the use of MOOC becomes a trend of high education over the world nowadays, eventually New York Times has been titled 2012 year is year of MOOC due to extremely fast and large scale of using MOOC for education in universities [9].

It is exciting to system designers that the connectivist style of MOOC has been based on connectivist learning technology base that described by S. Downes, [8].

Based on this base and above-mentioned learning ecosystem, this paper is developing one learning model for not massive open learning. This connective open online course (COOC) can be adaptive model for a practice of those education environments with developing infrastructure like Vietnam. The detailed design of COOC will be come back in next part in this paper.

\section{LEARNING ECOSYSTEM AND PRACTICAL DESIGN}

\section{A. Learning Ecosystem Terminology and Concept}

Berthelemy, M. has been transformed the concept of ecosystem from biology in order to defining learning ecosystem with an intention to learning for working [10].

Some other concepts of digital ecosystem or e-learning ecosystem has been used with the meaning of computer network infrastructure based on internet (Chang and West, 2006; Boley and Chang, 2007; Briscoe and De Wilde, 2008; Bo, 2009; Briscoe and Marinos, 2009); or regarded with ecology model for learning and teaching (Frielick, 2004). Same concept of learning ecosystem has been defined as e-learning infrastructure (Gütl and Chang 2008), or as implemented e-learning system (Uden, Wangsa et al., 2007); or as systems of tools that supporting learning (Ficheman and de Deus Lopes 2008).

The idea for the learning ecosystem that will be described in this paper is follow:

- This is holistic ecosystem for nurturing and developing learning individuals, groups and networks.

- This is system with a design for practical implementation.

- This is perspective of learning ecology model through networked learning environment.

While learning ecology emphasizes on learning network with more network characters such as dynamic, autonomy, peer, chaos and self-adaptive [6], [8], this learning ecosystem is intended to systemic character and technology context for this system, which are two factors that supporting the practical implementation.

\section{B. Learning Ecosystem Model}

Using principles of the system theory [11] and principles of networks and groups [8], the learning ecosystem can be described as a model consists of four (04) systems that connected tightly together (Fig. 1).

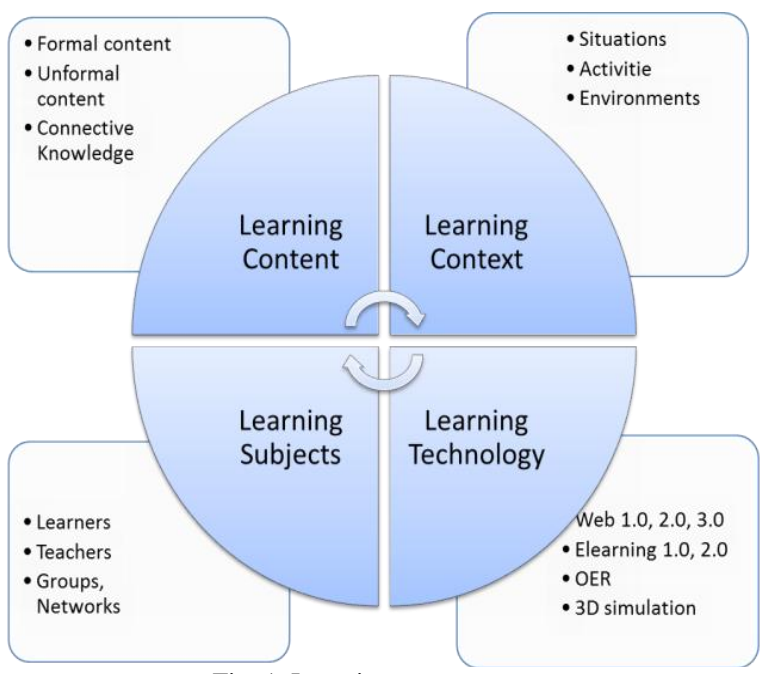

Fig. 1. Learning ecosystem.

\section{1) Learning subjects system}

A subject here is limited to ever teacher or leaner only, who directly participates in the learning process. There are not other educators or managers, etc. These learners and teachers are organized officially or self-organized into learning groups or networks. A group is more suitable for formal learning activities with a leader and given objectives. This group often has small number of members with clear structure and direction, and be controlled. Meanwhile, a network is more suitable for informal learning with peer connections, for research learning, learning by 
learner-demands. The network model allows self-expanded in a wide range and without limits on spaces or structures.

Based on concrete learning context (will be explained below), the learning subjects are organized to appropriate format such as individuals, groups or networks.

By pedagogy participatory, there are a change and shift between learners and teachers. Learners in their own learning activity are enable to contribute to curricula, by their own knowledge that created through various learning contexts such as seminars, forums, group exercises, essays, researches, projects; or through various publishing and sharing online tools such as blog, wiki, forum, personal web, etc. In term of connective perspective, a role of learner and teacher could be interchanged in some concrete learning contexts.

Hereunder is table (tab. 1) of some guidelines on designing learning subjects based on system theory [11]. Alternatively, this design could be done based on different methodologies such as Actor Network with a connection with technology system or contextual system.

\section{2) Learning content system}

Leaning content always is very important to every education system, from ancient era to current dynamic changing education system. Therefore, educators have been providing a huge forces to reform curricula by a given period in order to updating and following society requests and demands. Traditional learning curricula is very carefully selected and designed for each academic level. Normally, learning content is fixed by curricula in the form of formal textbooks, exercises book and the system of reference literature. When technology comes in, there are some other learning content formats such as multimedia $\mathrm{CD}$, online books, videos, audios or education software.

With greater and greater engagement and involvement of internet, there are more and more applications of online and open education resources for learning, for instance, Wikipedia or other wiki systems, Google search engine, shared learning materials on YouTube, Flickr.

Regarding with connective knowledge that created during connection between learners and teachers or in learning communities, this is a new type of learning content, which is coming in the learning process.

Therefore, the design of learning content system should be considered in the relation and connection with other systems - context, subjects and technology, especially with contextual design.

In term of the design of learning content system, there are various approaches, methods such as learning design approach, learning objects design, e.g IMS Learning Design [12], [13].

The interesting question here is that where a system of formal learning materials, including textbooks, exercises books and related books, relying is being in the whole learning content system of Learning Ecosystem? What are connections between these books and others learning resources online? A clarification on these questions are not being in this paper, and this is open for further study.

\section{3) Learning context system}

We can expose that learning context is emphasized as a most important element of whole learning ecosystem, in term of the shifting from content to context is key pedagogy approach of learning theories and education mindsets (Vygotsky [14], Brown \& Duguid, Lave \& Wenger, Figueiredo, Afonso \& Cunha, etc).

TABLE I: DESIGNING GUIDELINES FOR LEARNING SUBJECTS SYSTEM FROM THE VIEW OF SYSTEM THEORY

\begin{tabular}{|c|c|c|c|c|}
\hline & Input & Process & Output & $\begin{array}{l}\text { Feedback } \\
\text { and Control }\end{array}$ \\
\hline $\begin{array}{l}\text { Learner } \\
\text { Individual }\end{array}$ & $\begin{array}{l}\text { Learning } \\
\text { objects; } \\
\text { purpose; } \\
\text { personal } \\
\text { learning } \\
\text { demands; } \\
\text { personal } \\
\text { learning } \\
\text { capabilities }\end{array}$ & $\begin{array}{l}\text {-Curricula: } \\
\text { common or } \\
\text { individual; } \\
\text { basic or } \\
\text { advance; } \\
\text { foundation } \\
\text { or in-depth. } \\
\text { - Learning } \\
\text { model: } \\
\text { formal, } \\
\text { informal, } \\
\text { practicing. } \\
\text {-Learning } \\
\text { context: } \\
\text { classroom } \\
\text { lesson, } \\
\text { seminar, } \\
\text { conversation, } \\
\text { essay, } \\
\text { practicing, } \\
\text { exam, quiz, } \\
\text { applying, } \\
\text { researching, } \\
\text { self-learning. }\end{array}$ & $\begin{array}{l}\text {-Learning } \\
\text { result: scores, } \\
\text { dissertation. } \\
\text {-Knowledge } \\
\text { publish: } \\
\text { essay, } \\
\text { comment, } \\
\text { opinion, } \\
\text { dissertation, } \\
\text { research. } \\
\text {-Personal } \\
\text { satisfaction, } \\
\text { emotional } \\
\text { inspiration. }\end{array}$ & $\begin{array}{l}\text {-Career } \\
\text { development. } \\
\text {-Community } \\
\text { evaluation, } \\
\text { personal } \\
\text { image, } \\
\text { personal } \\
\text { prestige. } \\
\text {-Personal } \\
\text { satisfaction. }\end{array}$ \\
\hline $\begin{array}{l}\text { Group of } \\
\text { learners }\end{array}$ & $\begin{array}{l}\text { Common } \\
\text { objects of a } \\
\text { group, group } \\
\text { organization, } \\
\text { relationship } \\
\text { between } \\
\text { members. }\end{array}$ & $\begin{array}{l}\text { - Learning } \\
\text { format: } \\
\text { formal, } \\
\text { informal, } \\
\text { practicing. } \\
\text { - Learning } \\
\text { context: } \\
\text { essay, } \\
\text { practicing, } \\
\text { applying, } \\
\text { researching. }\end{array}$ & $\begin{array}{l}\text {-Result: } \\
\text { group's } \\
\text { exercises, } \\
\text { essay. } \\
\text {-Knowledge } \\
\text { publish: } \\
\text { essay, } \\
\text { dissertation, } \\
\text { research. } \\
\text {-Group } \\
\text { development. } \\
\text {-Result of } \\
\text { each member. }\end{array}$ & $\begin{array}{l}\text { - Evaluation } \\
\text { from } \\
\text { community. } \\
\text { - Check } \\
\text { connections } \\
\text { between } \\
\text { members. } \\
\text {-Impact of } \\
\text { group to } \\
\text { members. }\end{array}$ \\
\hline $\begin{array}{l}\text { Network } \\
\text { of } \\
\text { learners }\end{array}$ & $\begin{array}{l}\text { Network } \\
\text { connection, } \\
\text { connection } \\
\text { range, } \\
\text { connection } \\
\text { motivation. }\end{array}$ & $\begin{array}{l}\text {-Activities: } \\
\text { sharing, } \\
\text { arguing, } \\
\text { discussing, } \\
\text { commenting, } \\
\text { publishing. }\end{array}$ & $\begin{array}{l}\text {-Network } \\
\text { enhancement. } \\
\text {-Results of } \\
\text { network, } \\
\text { members, } \\
\text { sub-networks. }\end{array}$ & $\begin{array}{l}\text {-Evaluation } \\
\text { from } \\
\text { community. } \\
\text {-Impact from } \\
\text { group to } \\
\text { members. }\end{array}$ \\
\hline
\end{tabular}

Learning context is understood as "the set of circumstances that are relevant when someone needs to learn something" [15]. Learning context is conjunctive with content and learner. Context in the larger meaning is considered as an interaction [15] or "the ability for a learning object to interconnect various, similar events or statements" [16].

For more understandable format, learning contexts normally are accepted as learning activities, situations of learning and teaching, for instance, theoretical lesson, concept learning, skill learning, practice learning, learning through real situation, group exercise, presentation, essay, argument, comment, notation, etc.

Designing learning context is a researching field that has been gotten many interests at the end of 20 century. Firstly, there were researches on instruction design from instructivists (Vygotsky, 1978, Alexei Leont'ev, Alexander Luria), and from social and organizational contexts (Brown 
\& Duguid, 1991; Lave \& Wenger, 1991; Wenger, 1998).

Later on, the design and management of learning contexts, and without their meaning understanding, has been leading to additional theoretical frameworks not traditionally associated to learning, as noted below by Figueiredo \& Afonso [17]. One such framework is provided by Actor Network Theory (ANT) [18], a sociological theory used to help understanding social networks made up of human and non-human actors that create relationships of mutual dependence, mobilize other actors and resort to artifacts to reinforce their alliances and satisfy their interests (Callon \& Latour, 1981; Callon, 1986; Law, 1992). Another inspiring framework is Theory of Wholeness, proposed by Christopher Alexander.

The concept of design pattern, proposed by Alexander, Ishikawa \& Silverstein [19] to describe a problem that occurs over and over again and for which a solution has been established. These authors propose a standard format for the characterization of any pattern, which includes the description of the corresponding problem, its solution, and the clarification of the relationships between that pattern and the other patterns to which it is related. Once a pattern is created, which means that a problem/solution pair has been established, it can be used over and over again whenever that problem occurs.

Hereunder are guidelines suggested by this paper that related to designing learning context:

- Expecting on learning purposes and results.

- Establishing learning tasks and their nature.

- Mapping these tasks to appropriate learning means.

- Considering learning demand and portfolio of a learner.

- Defining common learning framework.

Selecting appropriate tools and spaces for learning ecosystem.

\section{4) Learning technology system}

Learning technology system is key factor to expanding and shifting of spaces and structures of the learning ecosystem, and designing of whole learning ecosystem in fact is relied on this technology system. As noted by Siemens G., "If ecologies are the spaces of learning, then networks are the structures of learning", this system actually is the medium for designing other systems of the learning ecosystem at all [6].

We are exposed that technology is very fast changing from year to year. The shifting is carrying out from fixed net-work to mobile network, from local to community range, and global social networks is playing more and more vitality to people. Due to fast changing technology environment, we cannot fix neither or either components of technology, only can define some core elements of the system at this moment.

Therefore, today, we can take software and tools from e-learning 1.0 and e-learning 2.0 and maybe some other applications to act as base of the learning technology system. The below table (Table II) is subjected to explain common technology elements for this system.

\section{5) Learning content system}

Leaning content always is very important to every education system, from ancient era to current dynamic changing education system. Therefore, educators have been providing a huge forces to reform curricula by a given period in order to updating and following society requests and demands. Traditional learning curricula is very carefully selected and designed for each academic level. Normally, learning content is fixed by curricula in the form of formal textbooks, exercises book and the system of reference literature. When technology comes in, there are some other learning content formats such as multimedia $\mathrm{CD}$, online books, videos, audios or education software.

With greater and greater engagement and involvement of internet, there are more and more applications of online and open education resources for learning, for instance, Wikipedia or other wiki systems, Google search engine, shared learning materials on YouTube, Flickr.

Regarding with connective knowledge that created during connection between learners and teachers or in learning communities, this is a new type of learning content, which is coming in the learning process.

Therefore, the design of learning content system should be considered in the relation and connection with other systems-context, subjects and technology, especially with contextual design.

In term of the design of learning content system, there are various approaches, methods such as system theory, learning theories (behaviorism, cognitivism, constructivism, instructivism, social learning, connectivism, etc), or contextual theories.

The interesting question here is that where a system of formal learning materials, including textbooks, exercises books and related books, relying is being in the whole learning content system of Learning Ecosystem? What are connections between these books and others learning resources online? A clarification on these questions are not being in this paper, and this is open for further study.

\section{Connective Open Online Course (COOC) Model}

\section{A. $c M O O C$ and $x M O O C$}

As per above mentioned, MOOC now has very huge pace on development worldwide, based on XMOOC, that type of content-based MOOC. There are hundreds top universities over the world that offer thousands MOOCs to students with free access and free of charges. Typical characters of these $\mathrm{xMOOC}$ are high cost for designing and addressed to big number of learners. Oppositely, cMOOC has been offered low cost MOOC and based on diversity, openness, autonomy and interactivity [8]. Below is table (Table III) for comparing these types.

\section{B. Connective Open Online Course}

As noted from above, $\mathrm{xMOOC}$ is costly and be subjected to big organization with a big number of learners, that are not suitable to Vietnam education practice, which is not ready by barriers such as cost, technical infrastructure, learner psychology, manner and management capability. At this moment, with taken key point is the ability for practical using here in Vietnam, this paper is suggesting connective open online course (COOC) model, based on cMOOC technology base and OER [10] for content.

There are ideas for this model:

- Learning model based on free, open, online courses

- Learning model with flexible delivery scheme, offered to learners from few to hundreds

- Using cMOOC learning technology base [8, slide 7]

- The content of courses can be delivered by teachers, learners or members of social networks with evaluation from 1) teachers or experts; 2) community. 
TABLE II: TECHNOLOGY TOOLS AND APPLICATION SOFTWARES

\begin{tabular}{|c|c|c|c|}
\hline Name of software & Description & Is good for... & Cons \\
\hline LMS/LCMS & $\begin{array}{l}\text { Learning (Content) Management System, } \\
\text { E.g Moodle, webCT, Blackboard }\end{array}$ & $\begin{array}{l}\text { This is online copy of traditional } \\
\text { learning model in internet. } \\
\text { Online Learning, virtual classroom. }\end{array}$ & $\begin{array}{l}\text { This is centralled system, high cost, } \\
\text { fixed content, not easy to updated or } \\
\text { connected to other systems. }\end{array}$ \\
\hline $\begin{array}{l}\text { Digital depository of } \\
\text { lecture notes, teaching } \\
\text { materials. } \\
\text { Open Education } \\
\text { Resources (OER) }\end{array}$ & $\begin{array}{l}\text { Open courseware or other teaching support } \\
\text { documents that digitized and stored in the web } \\
\text { in learning standard format like SCORM. }\end{array}$ & $\begin{array}{l}\text { Formal learning by curricula, or } \\
\text { self-learning. This is huge free content } \\
\text { supporting teaching and self-learning. } \\
\text { Can be accompanied with } \\
\text { LMS/LCMS. }\end{array}$ & $\begin{array}{l}\text { Costly to establish, only published } \\
\text { one time, not updated or linked } \\
\text { together. }\end{array}$ \\
\hline Blogs, web-blogs & $\begin{array}{l}\text { Personal or collective knowledge authoring } \\
\text { system with diary type, allows posting notes, } \\
\text { papers, comments, ideas of common or } \\
\text { specialized disciplines, by chronicle, and allows } \\
\text { sharing, discussing related opinions, e.g google } \\
\text { blogspot, wordpress. }\end{array}$ & $\begin{array}{l}\text { Informal learning, reseaching, } \\
\text { publishing knowledge, connective } \\
\text { knowledge. Supporting formal } \\
\text { learning. } \\
\text { Support performance learning }\end{array}$ & $\begin{array}{l}\text { Non-structured, informal learning } \\
\text { materials. Dependable on active } \\
\text { participation from learners. }\end{array}$ \\
\hline $\begin{array}{l}\text { Open specialized } \\
\text { knowledge system wiki }\end{array}$ & $\begin{array}{l}\text { The open specialized knowledge, represented } \\
\text { with encyclopedia format, allows users/learners } \\
\text { can create, edit, access, search, link content } \\
\text { items with format of wiki, e.g wikipedia. Using } \\
\text { wiki software to create appropriate wiki system, } \\
\text { e.g mediawiki, twiki. }\end{array}$ & $\begin{array}{l}\text { Support learning.. } \\
\text { Support active learning by the way that } \\
\text { learners can themselves develop own } \\
\text { knowledge. } \\
\text { Support search necessary knowledge. }\end{array}$ & $\begin{array}{l}\text { Dependable on active participation } \\
\text { from learners and community. }\end{array}$ \\
\hline Forums (internet) & $\begin{array}{l}\text { Forum is web-content managament by threads, } \\
\text { that created, posted by users/learners for open } \\
\text { discussion. Using forum softwares to create a } \\
\text { forum, e.g phpBB, vBuletin. }\end{array}$ & $\begin{array}{l}\text { Support learning by specialized } \\
\text { threads as questions or problems that } \\
\text { created by learners. High interactivity } \\
\text { with other members of forum. } \\
\text { Informal learning. }\end{array}$ & $\begin{array}{l}\text { Depend on admin, moderators or } \\
\text { participation of other members. }\end{array}$ \\
\hline Social network & $\begin{array}{l}\text { Social network allows connection between } \\
\text { persons, or groups by network, and sharing } \\
\text { comments, photos, ideas. Very high } \\
\text { connectivity, e.g Facebook, Twitter, Linkedn }\end{array}$ & $\begin{array}{l}\text { Learning in community, connection to } \\
\text { community, create image. } \\
\text { Supporting learning by links to other } \\
\text { learning resources. Informal learning }\end{array}$ & $\begin{array}{l}\text { Information though social network is } \\
\text { distributed, scrattered, informal and } \\
\text { difficult for evaluation. }\end{array}$ \\
\hline $\begin{array}{l}\text { Office tools. } \\
\text { Organizing, sharing, } \\
\text { storing tools in internet, } \\
\text { cload networks. }\end{array}$ & $\begin{array}{l}\text { These sofware such as Google Drives, } \\
\text { Mediashares, Slideshare, Youtube, Flickr allow } \\
\text { learners to share their knowledge in varios } \\
\text { formats: file, video, audio, musics, ppt, photos } \\
\text { in internet or cload networks, e.g Youtube, } \\
\text { Flickr, Slideshare, Mediashare, Google drives. }\end{array}$ & $\begin{array}{l}\text { Expanding personal learning } \\
\text { environment (PLE). } \\
\text { Technology environment for sharing, } \\
\text { publishing, and supporting design of } \\
\text { learning ecosystem. }\end{array}$ & $\begin{array}{l}\text { Need integration for establishing } \\
\text { whole system. } \\
\text { Depend on internet infrastructure. }\end{array}$ \\
\hline $\begin{array}{l}\text { Semantic software for } \\
\text { representing knowledge. }\end{array}$ & $\begin{array}{l}\text { Semantic networks, semantic webs for } \\
\text { specialized knowledge, allow users/learners to } \\
\text { create content and develop knowledge } \\
\text { following a set of given semantic ontological } \\
\text { rules, e.g Lexipedia, WorldNet, ConceptNet, } \\
\text { FOAF, NetBio. }\end{array}$ & $\begin{array}{l}\text { Specialized learning. } \\
\text { Researching. }\end{array}$ & $\begin{array}{l}\text { Costly. Not popular. } \\
\text { Depend on participation of } \\
\text { learners/users. }\end{array}$ \\
\hline $\begin{array}{l}\text { 3D simulations, 3D } \\
\text { virtual reality softwares, } \\
\text { 3D games }\end{array}$ & $\begin{array}{l}\text { These are 3D software tools for virtual } \\
\text { experiments or practising. Immersed learning in } \\
\text { full-3D virtual reality, e.g Crocodile, Second } \\
\text { life }\end{array}$ & Practise learning, skills learning. & Costly and time consumed. \\
\hline $\begin{array}{l}\text { Authoring tools for } \\
\text { coursewares, software } \\
\text { for building mindmap }\end{array}$ & $\begin{array}{l}\text { Softwares that allow teachers to design their } \\
\text { online lession; or build outlines, schema of } \\
\text { concepts to supports learners for better } \\
\text { understanding of knowledge, e.g Macromedia } \\
\text { Dreamweaver, eXe, Lectura; FreeMind, } \\
\text { Coogle, VUE, Wisemapping } \\
\end{array}$ & $\begin{array}{l}\text { Formal learning. } \\
\text { Self-learning. }\end{array}$ & $\begin{array}{l}\text { Request a lot forces from teachers to } \\
\text { do authoring or designing a lession. } \\
\text { One way teaching only. }\end{array}$ \\
\hline Bookmarking softwares & $\begin{array}{l}\text { Enable learners to add, annotate, edit, and share } \\
\text { bookmarks of web documents, and enact } \\
\text { managing, storing and searching internet } \\
\text { resources, e.g Pinterest, Diigo }\end{array}$ & $\begin{array}{l}\text { Supporting informal learning. } \\
\text { Researching. } \\
\text { To establishing personal learning } \\
\text { environment. }\end{array}$ & $\begin{array}{l}\text { Request learners to search, select and } \\
\text { organize necessary resources from } \\
\text { internet. } \\
\text { Information is scrattered, informal } \\
\text { for foundation learning. }\end{array}$ \\
\hline $\begin{array}{l}\text { Scientific databases } \\
\text { softwares }\end{array}$ & $\begin{array}{l}\text { Enable learners to search/register sientific } \\
\text { papers based on databases of big numbers of } \\
\text { registered scientific papers over the world, e.g } \\
\text { ScienceDirect, Google scholar, SpringerLink. }\end{array}$ & $\begin{array}{l}\text { Researching. } \\
\text { Self-learning. } \\
\text { Support performance learning }\end{array}$ & $\begin{array}{l}\text { Request learners to search, select } \\
\text { necessary documents. } \\
\text { Information is scrattered, informal } \\
\text { for foundation learning. }\end{array}$ \\
\hline
\end{tabular}

- The content of courses can be diversified, from simple video clip as KhanAcademy, or careful prepared by professors or group of teachers as Coursera.

- The content of courses can be based on OER with selection and localization to Vietnamese.

Based on model of learning ecosystem of above part, we can specify COOC based on learning context, then consequently design learning subjects system, learning content system and learning technology system based on one installed xCOOC technology base. Due to size of this paper is limited, we will focus on learning context system and learning technology system only.

\section{1) Learning context system}

Let consider four (04) master learning contexts:

- Massive learning for an aggregation of big number of students from group of universities for common, basic disciplines of foundation curricula. 
- Supporting to formal learning in university, conducting by main lecturer or a group of lecturers.

- Supporting to MOOC for enhancing learning result.

- Informal learning for a given specialized topic or course. For each master learning context, we can specify a system of contexts at different levels for each course, for instance, theoretical lectures, skill learning, exercises, practice learning, and then make designing context at the detailed level. We are able to combine this online learning with common learning framework that conducted at each class or school.

Designing learning context can be done by using pattern language that explained in above part of this paper.

\section{2) Learning technology system}

Based on cMOOC technology model [8, slide 7], we can suggest common learning technology system for COOC model with following main elements:

- A Moodle module for whole course has main page for the course, course's forum, learner registration page, and links to other modules.

- An wiki module for whole course: common information map; specialized knowledge of this course that accumulated year by year and organized as wiki format; exercises; links to other modules.

- A blog of the course: this is open blog for posting notes, comments, ideas that relevant to this specialization of this course; links to relevant blog or webpages.

- A Blog of personals (of teachers, learners or relevant persons) with the link engine to main blog of the course.

- A Facebook account of the course: this is a social tool for connecting learners and teachers and relevant persons, and the place for posting comments, messages or ideas from all relevant persons.

- A Twitter account of the course: there are links and connections to the course through various connections as social connections, connection through blog or connection through links to other modules.

- A RSS system for aggregating and feeding information between blogs and webpages of the course in Moodle and wiki system.

\section{ON-GOING PROJECTS FOR IMPLEMENTATION}

As per above mentioned, models of learning ecosystem and COOC are designed based on intention of practical implementation. Therefore we are trying to have these models in the learning practice. In order to applying the models of learning ecosystem and COOC, we have some projects that are on-going now in Hanoi Education University (HNUE):

- The project of designing Learning Ecosystem for one given course. The project consists of four phases: initial phase of designing, setup phase of installation of the technology system, exploration phase and evaluation phase to make necessary evaluation form for assessment of the model.

- The project of designing learning context system for courses of one academic faculty.

The project of designing one connective technology environment based on COOC model to supporting implementation of social and open project, and tagged to the program of new system of textbooks of national education system.

TABLE III: XMOOC AND CMOOC

\begin{tabular}{|c|c|c|}
\hline & xMOOC & cMOOC \\
\hline $\begin{array}{l}\text { Learning } \\
\text { model }\end{array}$ & $\begin{array}{l}\text { Centrallized; content- } \\
\text { based; commercial enable }\end{array}$ & $\begin{array}{l}\text { Distributed; } \\
\text { networked; free; } \\
\text { knowledge is acquired } \\
\text { from interaction }\end{array}$ \\
\hline $\begin{array}{l}\text { Learning } \\
\text { resources }\end{array}$ & $\begin{array}{l}\text { Content-fixed design by top } \\
\text { professors and delivered } \\
\text { thru companies like } \\
\text { Coursera, Edx, AI. }\end{array}$ & Diverse; Using OER \\
\hline $\begin{array}{l}\text { Designing } \\
\text { principle }\end{array}$ & Instructivism & $\begin{array}{l}\text { Openess; Autonomy; } \\
\text { Diversity; } \\
\text { Interactivity; } \\
\text { Connectivism }\end{array}$ \\
\hline Exam & $\begin{array}{l}\text { Auto-quizz; Multi/single } \\
\text { choice questionnaire }\end{array}$ & $\begin{array}{l}\text { Evaluated by peers (e.g } \\
5 \text { others peers) }\end{array}$ \\
\hline Cost & $\begin{array}{l}\text { High (15-50k USD per } \\
\text { course [20]) }\end{array}$ & Low cost; sharing \\
\hline $\begin{array}{l}\text { Apply } \\
\text { to... }\end{array}$ & $\begin{array}{l}\text { Formal learning; big } \\
\text { organizations; big named } \\
\text { universities }\end{array}$ & $\begin{array}{l}\text { Applied to common } \\
\text { courses; distance } \\
\text { learning; informal } \\
\text { learning; support } \\
\text { learning }\end{array}$ \\
\hline
\end{tabular}

\section{CONCLUSION}

Connectivism gives new view to reform the traditional education. We are trying to build the applied models in order to contribute to this reformation, using ideas of connectivism. Based on proposed model of learning ecosystem, this paper has been designed one theoretical and holistic framework for practical implementation, and using COOC model we can apply some pilot projects for MOOC in Vietnam.

Further study is deepening analysis of structure of each system of learning ecosystem and procedural design of COOC model in practice. One study is subjected to the question that mentioned in part II of this paper about a relationship between textbook system and other components of learning ecosystem.

\section{REFERENCES}

[1] S. Downes. (2012). Connectivism and Connective Knowledge Essays on meaning and learning networks. [Online]. Available: http://www.downes.ca/files/Connective_Knowledge-19May2012.pdf.

[2] G. Siemens. (2004). Connectivism: A learning theory for the digital age. International Journal of Instructional Technology and Distance Learning. [Online]. Available: http://www.elearnspace.org/ Articles/connectivism.htm.

[3] Institute for Research on Educational Development. (2011). Overview on Vietnam's Education System. [Online]. Available: http://www.ired.edu.vn/en/EducationInVietNam/Read/overview-on-vi etnam-s-education-system.

[4] T. J. Vallely, B. Wilkinson. (2008). Vietnamese Higher Education: Crisis and Response. Memorandum Higher Education Task Force, Harvard Kennedy School. [Online]. Available: http://www.hks.harvard.edu/innovations/asia/Documents/HigherEduc ationOverview112008.pdf.

[5] G. Siemens. (April 6, 2006). Learning, assessment, outcomes, ecologies. [Online]. pp. 57. Available: http://www.connectivism.ca/?

[6] G. Siemens. (2008). New structures and spaces of learning: The systemic impact of connective knowledge, connectivism, and networked learning. Presented for/to: Universidade do Minho Encontro sobre Web $2.0 \quad$ Braga. [Online]. Available: http://elearnspace.org/Articles/systemic_impact.htm.

[7] A. McAuley, B. Stewart, G. Siemens, and D. Cormier. The MOOC Model for Digital Practice, Elearnspace Web. [Online]. Available: http://www.elearnspace.org/Articles/MOOC_Final.pdf. 
[8] S. Downes, MOOCs in Context, Stephen Downes blog 13-3-2013. [Online]. Available: http://www.downes.ca/presentation/312.

[9] L. Pappano, The Year of the MOOC - The New York Times, November $2,2012$.

[10] M. Berthelemy. (2010). Definition of a learning ecosystem. [Online]. Available:

http://learningconversations.co.uk/main/index.php/2010/01/10/the-cha racteristics-of-a-learning-ecosystem?

[11] D. Schoech. (2004). Concept Paper: Systems Theory. [Online]. Available:

http://wweb.uta.edu/faculty/schoech/cussn/courses/5306/coursepack/t heory_systems.pdf.

[12] IMS LD. (2003). Learning Design specification v1. [Online]. Available: http://www.msglobal.org/learningdesign.

[13] R. Koper and B. Olivier, "Representing the Learning Design of Units of Learning," Educational Technology \& Society, vol. 7, no. 3, pp. 97-111, 2004.

[14] L. Vygotsky, Thought and language. Cambridge, MA: MIT Press, 1986.

[15] A. D. Figueiredo, "Learning Contexts: a Blueprint for Research. Interactive Educational Multimedia," no. 11, pp. 127-139, 2005.

[16] S. Downes. (2004). What is a Learning Context? [Online]. Available: http://www.downes.ca/post/18.
[17] A. D. Figueiredo and A. P. Alfonso, Context and Learning: A Philosophical Framework, Idea Group Inc., 2006.

[18] P. Latour, Reassembling the Social-An Introduction to Actor-Network-Theory, Oxford University Press Inc., New York, 2005.

[19] C. Alexander, S. Ishikawa, M. Silverstein, M. Jacobson, I. Fiksdahl-King, and S. Angel, A Pattern Language, New York: Oxford University Press, 1977.

[20] E. Carol. MOOC's An Analysis for BCIT. [Online]. Available: https://landing.athabascau.ca/file/download/148565.

[21] N. M. Hùng, "Từ lý thuyết học tập kết nối gợi mở cho việc ứng dụng công nghệ trong học tập," Tap chí khoa học giáo duc- Truờng Đai hoc Su phạm Hà Nội, vol. 57, no. 9, 2012, pp. 68-77, 2012, in Vietnamese.

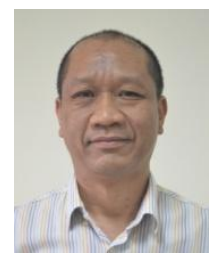

Nguyen Manh Hung is a lecturer and deputy director of IT Centre at Hanoi National University of Education, Vietnam.

He holds a $\mathrm{PhD}$ in physics-mathematics at State University of Chisinau, Moldova in 1991. His main research interests are e-learning and computer network. 